\title{
Investigation of Pre-service Social Studies Teachers' Self-Efficacy Perception of and Attitudes Towards the Profession of Teaching
}

\author{
Nur İkbal Yildiz', Harun Şahin 2,* \& Feti Çelik ${ }^{3}$ \\ ${ }^{1}$ Educational Sciences Institute, Mehmet Akif Ersoy University, Turkey \\ ${ }^{2}$ Faculty of Education, Department of Educational Sciences Curriculum and Instruction, Akdeniz University, Turkey \\ ${ }^{3}$ Faculty of Education, Department of Educational Sciences Curriculum and Instruction, Mehmet Akif Ersoy \\ University, Turkey
}

*Correspondence: Educational Sciences Institute, Mehmet Akif Ersoy University, Turkey. E-mail: harunsahin@akdeniz.edu.tr

This study was produced from Master's Thesis supported by Burdur MAKU Scientific Research Projects unit.

Received: March 18, 2020

doi:10.5430/jct.v9n2p47
Accepted: April 7, $2020 \quad$ Online Published: May 16, 2020

URL: https://doi.org/10.5430/jct.v9n2p47

\begin{abstract}
The current study aimed to investigate pre-service social studies teachers' self-efficacy perception of their ability to teach geography and attitudes towards the profession of teaching in relation to the variables of gender and university attended. The study is a descriptive study employing the survey model. The research sample was determined from the universities, where there were two public universities represented from each of the seven geographical regions, and a fourth-year student of social studies teaching in the spring semester of the 2017-2018 academic year. The study was carried out with the participation of 654 pre-service social studies teachers from 14 different universities across Turkey. In order to collect data, "The Geography Teaching Self-Efficacy Scale" and "The Scale of Attitudes towards the Profession of Teaching" were used. In the analysis of the collected data, arithmetic mean, standard deviation, independent samples t-test and one-way variance analysis (ANOVA) were used. According to the findings of the current study, self-efficacy perceptions related to geography teaching and their attitudes towards the profession are high. The mean scores taken from the whole self-efficacy perception scale and its sub-dimensions were found to be not varying significantly depending on the gender variable while they were found to be varying significantly depending on the variable of the university attended. On the other hand, the attitudes towards the profession of teaching were found to be varying significantly depending on both of the variables.
\end{abstract}

Keywords: pre-service teachers, self-efficacy perception, social studies teaching, attitude

\section{Introduction}

The aim of education and training is to provide learning. The person providing the education in the institutions providing formal education is the teacher (Erden, 2007). Many factors such as education program, quality of teaching materials, physical environment and technological infrastructure are effective in reaching the aims of the education system. But the teacher has a feature that determines and directs beyond these elements (Demirel and Kaya, 2005; Demirtaş, Cömert, and Özer, 2011).

In the Basic Law of National Education, teaching is defined as "a specialist profession that assumes the state's education, training and related management duties" (TBMM Legislation, 2019). Therefore, only teachers are the ones who will implement the curriculum. The teachers who undertake this task and the candidates who have taken steps in this path must bear the duties and responsibilities of the teaching profession. There are professional knowledge, skills, values and attitudes that must be possessed in order to fulfil duties and responsibilities specific to the profession. The competences that the teachers and prospective teachers think of the competences mentioned have the same concept of "self-efficacy". 


\subsection{Self-efficacy}

Self-efficacy perception introduced as a new concept in the social learning theory refers to the individual's own judgement and belief about his/her ability to cope with the situations he/she encounters, and about his/her capacity to organize and carry out the activities necessary to perform a certain performance (Bandura, 1994). In this context, self-efficacy can be expressed as a belief in self resulting from the individual's awareness of his/her abilities to accomplish a task (Demirtaş, et al., 2011; Yaman, Koray, and Altunçekiç, 2004). In education, self-efficacy perception can be defined as the belief of the teacher in his/her own teaching ability to bring about positive changes in students' achievement levels and behaviours (Schriver and Czerniak, 1999).

There are four sources of self-efficacy that are effective in the development of self-efficacy perception. The most important of these sources is self-experiences. The others are indirect experiences gained from social models, the individual psychological state of the behaviours he/she will exhibit and his/her verbal expressions about the behaviours he/she has exhibited (Bandura, 1997). These sources can affect the self-efficacy perception in two different ways, positively and negatively. People who have positive self-efficacy perception have developed self-confidence, courage and belief, they can cope with complex events, solve the problems they face and they are successful at home, school and profession. Exact opposites of these features are observed in individuals with low self-efficacy perception (Aliyev, 2015).

It is important to determine the professional competencies and self-efficacy of pre-service teachers in order for them to be able to carry out effective teaching in their professional lives because the existing research indicates that the teacher's self-efficacy perception about teaching is effective in his/her performance of teaching (Brownell and Pajares, 1999).

Although self-efficacy is determined in general terms, it is more important to examine competencies specific to a field. Karadeniz and Sarı (2011) emphasized "the determination of self-efficacy in private areas since general self-efficacy cannot adequately reflect the beliefs about the ability to provide education in a particular field". Although there are branches of science such as sociology, anthropology, economics and political science in the Social Studies curriculum in recent years, geography has an important place both in scope and function in social studies (Bilgili, 2009). It is important for the Social Studies teacher candidates to reach a standard of geography competencies in order to achieve the aim of the Social Studies program (Akengin, Şahin, Kaya, Bengiç and Sargın, 2010). Because it is also aimed to reach professional competence among the objectives of the training given to train teachers (Demirtaş et al., 2011).

\subsection{Attitude}

One of the most important factors that affect the level of satisfaction and commitment of pre-service teachers who have set their hearts on the teaching profession is their attitude towards the profession (Demirtaş et al., 2011). According to Allport (1935, p.810), attitude is "a state of emotional and mental preparedness that is shaped by experiences and that has directing and dynamic influence on the behaviours of the individual towards all objects and situations". In other words, attitude is a person's tendency to display positive or negative behaviour towards any event, object or person. In this definition, it is pointed out that the direction of attitudes can be positive, negative or neutral (Gömleksiz and Kan, 2013).

Since the concept of attitude does not have a physical dimension, it is not directly observable. It is a tendency assumed to exist on the basis of individuals' expressions and observable behaviours. This tendency consists of three elements; cognitive, affective, and behavioural and it is assumed that there is internal consistency between these elements. According to this assumption, if what the individual knows about a subject entails his/her adapting a positive view of the subject, this is called the "cognitive element", the individual's having positive emotions on the subject is called the "affective element" and if the individual shows this with his/her words and behaviours, then it is called the "behavioural element" (İnceoğlu, 1993).

For pre-service social studies teachers who have come to the last stage of their pre-service training process to exhibit effective teaching performance in their professional career, they need to have positive attitudes towards the profession and high self-efficacy of their teaching ability.

In the study of Çapri and Çelikkaleli (2008), the attitudes and professional competence perceptions of teacher candidates towards the profession were handled according to gender, program and faculty variables. According to the findings obtained as a result of the research, it was found that the gender variable had a significant effect on the attitudes of teacher candidates towards teaching, and the effect of the program and faculty variables was not significant. It was observed that the effect of gender, program and faculty variables determined by the researcher on 
teacher candidates' proficiency beliefs was found to be significant.

As a result of the findings obtained by Demirtaş, Cömert and Özer (2011), the self-efficacy beliefs of teacher candidates were found to be a significant difference in terms of gender and curriculum, and their attitudes towards teaching profession did not differ significantly from the variables determined by the researchers. A low-level positive relationship has emerged between the pre-service teachers' self-efficacy beliefs and their attitudes towards the teaching profession.

Şahin (2013), in his study with prospective teachers registered in pedagogical formation education, both self-efficacy perception and attitude levels of prospective teachers did not differ according to gender and age. As a result of the analysis of the data, it was found that the difference between the self-efficacy perception levels in favour of the graduates from the verbal department, and the difference between the attitude levels in favour of the graduates from the mathematics department.

According to the results obtained from his research findings, Nakip (2015) stated that while there is a moderate meaningful relationship between self-efficacy perception levels and attitudes towards teaching profession, the gender of the students did not cause a significant difference.

According to the results of the research by Şimşek (2016), the geographical self-efficacy of the participants did not differ by gender, but there was a significant difference compared to the university. According to the results of the attitude towards geography, when the whole scale was considered, there was a significant difference by gender, but no difference by university.

Kaçar (2018) determined that the attitudes and competencies of social studies teacher candidates did not differ according to the gender variable.

In the current study, it was attempted to determine the relationship between self-efficacy and attitude by examining the pre-service social studies teachers' self-efficacy perceptions of their ability to teach geography and their attitudes towards the teaching profession in relation to the variables of gender and the university attended. In this connection, an answer to the question "Do the pre-service social studies teachers' self-efficacy perception of their ability to teach geography and attitudes towards the profession of teaching vary significantly depending on gender and the university attended?" was sought.

Within the context of the main research problem above, answers to the following sub-problems were also sought.

1. What is the level of the pre-service social studies teachers' self-efficacy perception of their ability to teach geography?

2. Does the pre-service social teachers' self-efficacy perception of their ability to teach geography vary significantly depending on gender?

3. Does the pre-service social teachers' self-efficacy perception of their ability to teach geography vary significantly depending on the university attended?

4. What are the pre-service social studies teachers' attitudes towards the profession of teaching?

5. Do the pre-service social studies teachers' attitudes towards the profession of teaching vary significantly depending on gender?

6. Do the pre-service social studies teachers' attitudes towards the profession of teaching vary significantly depending on the university attended?

\section{Method}

\subsection{Research Model}

The study employed the descriptive survey model. The descriptive survey model aims to reveal the past or present states of events or phenomena or some certain features of these events or phenomena as they were or are. It aims to describe the case as carefully as possible and as exactly as it is (Cebeci, 2014; Karasar, 2013; Büyüköztürk, Kılıç, Akgün, Karadeniz, and Demirel, 2010).

\subsection{Population and Sample}

The population of the study is comprised of the senior students attending the Departments of Social Studies Teaching in the Education Faculties of 57 different state universities out of 112 state universities in Turkey in 2018. The sample of the study on the other hand was selected as follows: first two universities from each of the seven regions of 
Turkey were selected; thus, a total of 14 universities accordingly 14 education faculties of these universities were determined by means of the stratified sampling method; one of the probability-based sampling methods, and then the students to constitute the sample of the study were randomly selected from among all the senior students attending the Departments of Social Studies Teaching of these 14 education faculties in the spring term of the 2017-2018 academic year. 654 teacher candidates try to investigate. According to the 2014 ÖSYS (Student Selection and Placement System) Higher Education Programs and Quotas Guide, the student quota placed in the social studies teacher indicates the $16.65 \%$ of the universe of the research. The stratified sampling method is a method that aims to allow each stratum from the population to be included in the sample by constructing sub-strata and thus to construct a more heterogeneous sample (Büyüköztürk et al., 2010). The reason why only fourth grade pre-service teachers are included in the sample of the study is that the collected data will be more valid due to the completion of the education of the department's field courses and professional knowledge courses.

\subsection{Data Collection Tools}

In order to collect data, "The Geography Teaching Self-Efficacy Scale" and "The Scale of Attitudes towards the Profession of Teaching" were used after the required permissions were granted from the developers of the scales. Some personal information items were added to the scales to collect data about the gender of the participants and the university they attend.

The self-efficacy scale: The scale developed by Karadeniz and Sar1 (2011) to measure the self-efficacy in geography teaching consists of four sub-dimensions; "the self-efficacy in applying (using) geography knowledge", "the self-efficacy in guiding the teaching process", "effective teaching self-efficacy" and "self-efficacy in geography skills" and explains $41.22 \%$ of the total variance. In order to determine the construct validity of the scale, Varimax orthogonal rotation (Rotated Component Matrix) technique was applied to reveal the dimensions of its natural structure. In the first sub-dimension, there are 18 items; in the second sub-dimension, there are 11 items; in the third sub-dimension, there are 9 items and in the fourth sub-dimension, there are 7 items; thus, a total of 45 items. Twelve items $(19,20,21,25,26,27,29,39,40,41,44,45)$ are negative. The scale items are designed as five-point Likert scale items ranging from 5 points for "strongly agree" to 1 point for "strongly disagree". The highest score to be taken from the scale is 225 while the lowest score to be taken is 45 . The negative items in the scale are reverse scored. The Cronbach Alpha $(\alpha)$ reliability coefficients found for the scale are as follows; .91 for the first sub-dimension, .78 for the second sub-dimension, .83 for the third sub-dimension and .59 for the fourth sub-dimension and .92 for the whole scale. These values show that the reliability of both the sub-dimensions except for the fourth sub-dimension and the whole scale is really high.

For the current study, the preliminary trial application of the geography self-efficacy scale was conducted with 48 pre-service teachers who were the senior students in Mehmet Akif Ersoy University and these students were not included in the sample. The reliability coefficient found as a result of the reliability analysis conducted on the data obtained from the preliminary trial application of the scale was calculated to be .94. According to Büyüköztürk (2019), the reliability coefficient that is 70 and above is considered sufficient for the reliability and internal consistency of the test scores. Thus, we can say that the reliability of the self-efficacy scale, which is one of our data collection tools, is high.

The scale of attitudes towards the profession of teaching: The scale developed by Üstüner (2006) to measure the attitudes towards the profession of teaching is a uni-dimensional scale consisted of 24 positive and 10 negative items; thus, a total of 34 items. The items 2, 5, 6, 7, 8, 15, 20,21, 30, 32 are negative items. The scale is a five-point Likert scale ranging from 5 points for "strongly agree" to 1 point for "strongly disagree". The negative items in the scale are reverse scored. The highest score to be taken from the attitude scale is 170 while the lowest score is 34 . Test-retest method was used while the scale was developed and as a result of two tests, the reliability coefficient in terms of score consistency was found to be .72. The internal reliability coefficient (Cronbach Alpha) was found to be .93. It was observed that factor load values, which are accepted as an indicator of the construct validity of the scale, ranged between .74 and .41 and that the factor explained $30 \%$ of the total variance. The item test correlation of each item was examined with the total score of the scale, and the item test correlation values varied between .74 and .42 . Criterion scale validity of the scale is .89 .

For the current study, the preliminary trial application of the attitude scale was conducted with 48 pre-service teachers who were the senior students in Mehmet Akif Ersoy University and these students were not included in the sample. The reliability coefficient found as a result of the reliability analysis conducted on the data obtained from the preliminary trial application of the scale was calculated to be .94 . If a data collection tool used with different groups in different times yield similar results, then it can be argued to be a reliable tool. 


\subsection{Data Collection}

After obtaining the necessary permissions from 14 universities in the sample, data was obtained in a single session in the context of volunteering for 654 teacher candidates studying in the fourth grade of the social sciences teaching department of the education faculties of the faculties of education in 2017-2018 academic year.

\subsection{Data Analysis}

Before starting the analysis of the data to elicit the pre-service social studies teachers' perception of their ability to teach geography and attitudes towards the profession of teaching, first normality values were checked. The data were found to be exhibiting a normal distribution. Findings for the analysis are given in Table 1.

Table 1. Normality Values of Data

\begin{tabular}{ccccc}
\hline Scales & Kolmogorov-Smirnov & Skewness & Kurtosis & Shapiro-Wilk \\
\hline Self-Efficacy Scale for Geography Teaching &, $008^{*}$ &,- 132 &, 537 &, 002 \\
Attitude Scale on Teaching Profession &, $000^{*}$ &,- 951 &, 736 &, 000 \\
\hline $\mathrm{p}<, 05$ & & &
\end{tabular}

According to the findings given in Table 1, the fact that the coefficient of skewness and kurtosis is between +1.5 and -1.5 indicates that the data fulfils the normality values (Tabachnick and Fidell, 2015). Therefore, parametric analyses can be made. In addition, when the Kolmogorov-Smirnov values are analysed, it is seen that the data are normally distributed $(\mathrm{p}<, 05)$. Kolmogorov-Smirnov was preferred because the sample size was over 50 .

Arithmetic means and standard deviation values were calculated to determine the pre-service teachers' self-efficacy perception of their ability to teach geography and attitudes towards the profession of teaching. When determining the levels of the five-point Likert scales as low, medium and high, the limits taken are; It was characterized as low score between 1.00 - 2.32, medium level between 2.33 - 3.65 and high level between $3.66-5.00$. In order to determine whether self-efficacy perception and attitudes vary significantly depending on gender, independent samples t-test was used. One Way Variance Analysis (ANOVA) was used to determine whether they vary significantly depending on the university attended. While the analysis to be conducted to determine whether the difference between the means of two independent samples is significant is t-test, ANOVA should be preferred when the number of variables to be investigated is more than two (Büyüköztürk, 2019).

\section{Results}

\subsection{Results Related to the First Sub-problem}

In order to investigate the first sub-problem of the study "What is the level of the pre-service social studies teachers' self-efficacy perception of their ability to teach geography?", arithmetic means and standard deviations values were calculated.

Table 2. Distribution Related to Self-efficacy Perception

\begin{tabular}{lcccl}
\hline Scales & $\mathrm{n}$ & $\overline{\boldsymbol{X}}$ & $\mathrm{SD}$ & Response Option \\
\hline Geography Teaching Self-Efficacy Scale & 654 & 3,70 & \multirow{2}{*}{48} & Agree \\
\hline
\end{tabular}

In line with the data in Table 2, it has been determined that the self-efficacy perception levels of the social studies teacher candidates regarding geography teaching are at a high level with an average of 3.70 .

\subsection{Results Related to the Second Sub-problem}

In order to investigate the second sub-problem of the study "Does the pre-service social teachers' self-efficacy perception of their ability to teach geography vary significantly depending on gender?", independent samples t-test was conducted. The findings of this analysis are presented in Table 3. 
Table 3. Geography Teaching Self-efficacy Perception Scores t-Test Results by Gender

\begin{tabular}{|c|c|c|c|c|c|c|c|}
\hline Sub-dimensions & Gender & $\mathrm{n}$ & $\bar{X}$ & S & $\mathrm{SD}$ & $\mathrm{t}$ & $\mathrm{p}$ \\
\hline Self-efficacy in applying (using) & Female & 340 & 67.83 & 9.26 & 652 & -1.43 & .15 \\
\hline geography knowledge & Male & 314 & 68.91 & 10.10 & & & \\
\hline Self-efficacy in guiding the & Female & 340 & 39.58 & 6.44 & 652 & -.53 & .59 \\
\hline teaching process & Male & 314 & 39.86 & 7.15 & & & \\
\hline \multirow[t]{2}{*}{ Effective teaching self-efficacy } & Female & 340 & 33.69 & 5.24 & 652 & .79 & .43 \\
\hline & Male & 314 & 33.35 & 5.55 & & & \\
\hline \multirow[t]{2}{*}{ Self-efficacy in geography skills } & Female & 340 & 25.20 & 4.81 & 652 & .32 & .74 \\
\hline & Male & 314 & 25.07 & 4.92 & & & \\
\hline \multirow[t]{2}{*}{ Total self-efficacy } & Female & 340 & 166.29 & 21.31 & 652 & -.53 & .59 \\
\hline & Male & 314 & 167.20 & 22.44 & & & \\
\hline
\end{tabular}

$* \mathrm{p}<.05$

As can be seen in Table 3, the self-efficacy perception mean scores taken by the pre-service teachers from both the sub-dimensions of the self-efficacy scale and from the whole scale do not vary significantly depending on gender $(\mathrm{p}>.05)$. The male pre-service social studies teachers' general mean score of the self-efficacy perception of their ability to teach geography is $(\bar{X}=167.20)$ while that of the female pre-service teachers is $(\bar{X}=166.29)$. When we evaluate the mean scores taken from the sub-dimensions presented in Table 3, it is seen that the mean score of the male pre-service teachers taken from the first sub-dimension "self-efficacy in applying geography knowledge" is higher than that of the female pre-service teachers $\quad\left(\overline{\mathrm{x}}_{\text {Male }}=68.91>\overline{\mathrm{X}}_{\text {Female }}=67.83\right)$. There is a small difference between the mean scores taken from the second sub-dimension "self-efficacy in guiding the teaching process" in favour of the male pre-service teachers $\left(\overline{\mathrm{x}}_{\text {Male }}=39.86>\overline{\mathrm{x}}_{\text {Female }}=39.58\right)$. Between the mean scores taken from the third sub-dimension "effective teaching self-efficacy", there is a difference in favour of the female pre-service teachers $\left(\overline{\mathrm{x}}_{\mathrm{Female}}=33.69>\right.$ $\left.\overline{\mathrm{x}}_{\text {Male }}=33.35\right)$. In the fourth sub-dimension "self-efficacy in geography skills", the mean score of the female pre-service teachers is higher than that of the male pre-service teachers $\left(\overline{\mathrm{x}}_{\text {Female }}=25.20>\overline{\mathrm{x}}_{\text {Male }}=25.07\right)$. In light of all these findings, it can be said that the female pre-service social studies teachers' mean scores taken from the sub-dimensions of effective teaching self-efficacy and self-efficacy in geography skills are higher than those of the male pre-service teachers while the male pre-service social studies teachers' mean scores taken from the sub-dimensions of self-efficacy in applying the geography knowledge and self-efficacy in guiding the teaching process are higher than those of the female students. Moreover, the sub-dimension in which both the female and male pre-service teachers see themselves the most self-efficient is self-efficacy in applying the geography knowledge.

\subsection{Results Related to the Third Sub-problem}

In order to investigate the third sub-problem of the study "Does the pre-service social teachers' self-efficacy perception of their ability to teach geography vary significantly depending on the university attended?", one-way variance analysis (ANOVA) was conducted. 
Table 4. ANOVA Results of Geography Teaching Self-efficacy Perception Scores by University

\begin{tabular}{|c|c|c|c|c|c|c|}
\hline Sub-dimensions & $\begin{array}{l}\text { Source of the } \\
\text { Variance }\end{array}$ & $\begin{array}{l}\text { Sum of } \\
\text { Squares }\end{array}$ & SD & Mean Squares & $\mathrm{F}$ & $\mathrm{p}$ \\
\hline \multirow{2}{*}{$\begin{array}{l}\text { Self-efficacy in applying (using) } \\
\text { geography knowledge }\end{array}$} & Between-groups & 2216.41 & 13 & 170.49 & 1.85 & $.033 *$ \\
\hline & Within-groups & 59020.99 & 640 & 92.22 & & \\
\hline \multirow{2}{*}{$\begin{array}{l}\text { Self-efficacy in guiding the } \\
\text { teaching process }\end{array}$} & Between-groups & 2139.74 & 13 & 164.60 & 3.77 & $.000 * *$ \\
\hline & Within-groups & 27966.21 & 640 & 43.70 & & \\
\hline \multirow{2}{*}{ Effective teaching self-efficacy } & Between-groups & 440.16 & 13 & 33.86 & 1.17 & .299 \\
\hline & Within-groups & 18556.95 & 640 & 28.99 & & \\
\hline \multirow{2}{*}{ Self-efficacy in geography skills } & Between-groups & 935.29 & 13 & 71.94 & 3.17 & $.000 * *$ \\
\hline & Within-groups & 14506.33 & 640 & 22.67 & & \\
\hline \multirow{2}{*}{ Total Self-efficacy } & Between-groups & 17263.88 & 13 & 1327.99 & 2.89 & $.000 * *$ \\
\hline & Within-groups & 294435.67 & 640 & 460.06 & & \\
\hline
\end{tabular}

As can be seen in Table 4, the pre-service social studies teachers' self-efficacy mean scores taken from the sub-dimensions of self-efficacy in applying geography knowledge $(\mathrm{F}(13.640)=1.849, \mathrm{p}<.05)$, self-efficacy in guiding the teaching process $(\mathrm{F}(13.640)=3.767, \mathrm{p}<.01)$, self-efficacy in geography skills $(\mathrm{F}(13.640)=3.174, \mathrm{p}<.01)$ and from the whole self-efficacy scale $(\mathrm{F}(13.640)=2.887, \mathrm{p}<.01)$ vary significantly depending on the university attended.

No significant difference was found in the sub-dimension of effective teaching self-efficacy $(F(13.640)=1.168$, $\mathrm{p}>.05)$. That is, the pre-service social studies teachers' effective teaching self-efficacy perception does not vary significantly depending on the university attended.

In order to find the source of the differences observed in the pre-service teachers' self-efficacy perceptions depending on the university attended as a result ANOVA, one of the Post-Hoc multi-comparison techniques, the LSD (Least Significant Difference) technique was preferred. The results of the LSD test analysis are given in Table 5.

As can be seen in Table 5, in paired comparisons made to investigate the relationship between the pre-service teachers' self-efficacy perception of their ability to teach geography and the university they attend, a significant difference was found between Adnan Menderes University and Dokuz Eylül University in favour of Adnan Menderes University, between Adnan Menderes University and Yıldız Teknik University in favour of Yıldız Teknik University, between Akdeniz University and Dokuz Eylül University in favour of Akdeniz University, between Atatürk University and Dokuz Eylül University in favour of Atatürk University, between Çukurova University and Dokuz Eylül University and Gaziantep University in favour of Çukurova University, between Dicle University and Dokuz Eylül University and Gaziantep University in favour of Dicle University, between Dokuz Eylül University and Gazi University, Giresun University, Karadeniz Teknik University, Marmara University, Necmettin Erbakan University, Yıldız Teknik University, and Van Yüzüncü Yıl University not in favour of Dokuz Eylül University but in favour of the other universities, between Gaziantep University and Yıldız Teknik University and Van Yüzüncü Yı1 University not in favour of Gaziantep University but in favour of the other universities, between Giresun University and Yıldız Teknik University in favour of Yıldız Teknik University and between Marmara University and Yıldız Teknik University in favour of Yıldız Teknik University. 
Table 5. LSD Results of Geography Teaching Self-efficacy Perception Scores by University

\begin{tabular}{|c|c|c|c|c|c|}
\hline Scale & University (i) & University (j) & $\overline{\mathrm{X}}_{\mathrm{i}}-\overline{\mathrm{X}}_{\mathrm{j}}$ & $\mathrm{SH}$ & $\mathrm{p}$ \\
\hline \multirow{19}{*}{$\begin{array}{l}\text { Geography } \\
\text { Teaching } \\
\text { Self-Efficacy } \\
\text { Scale }\end{array}$} & \multirow{2}{*}{$\begin{array}{l}\text { Adnan } \quad \text { Menderes } \\
\text { University }\end{array}$} & Dokuz Eylül University & $13.40(*)$ & 5.27 & .011 \\
\hline & & Yıldız Teknik University & $-10.82(*)$ & 5.37 & .044 \\
\hline & Akdeniz University & Dokuz Eylül University & $16.34(*)$ & 4.65 & .000 \\
\hline & Atatürk University & Dokuz Eylül University & $15.79(*)$ & 4.52 & .001 \\
\hline & \multirow{2}{*}{ Çukurova University } & Dokuz Eylül University & $22.22\left(^{*}\right)$ & 4.99 & .000 \\
\hline & & Gaziantep University & $13.16(*)$ & 4.84 & .007 \\
\hline & \multirow{2}{*}{ Dicle University } & Dokuz Eylül University & $18.45(*)$ & 4.32 & .000 \\
\hline & & Gaziantep University & $9.39(*)$ & 4.14 & .024 \\
\hline & \multirow{7}{*}{ Dokuz Eylül University } & $\begin{array}{l}\text { Gazi } \\
\text { University }\end{array}$ & $-18.31(*)$ & 5.09 & .000 \\
\hline & & Giresun University & $-13.40(*)$ & 4.54 & .003 \\
\hline & & Karadeniz Teknik University & $-16.57(*)$ & 4.29 & .000 \\
\hline & & Marmara University & $-13.00(*)$ & 5.27 & .014 \\
\hline & & Necmettin Erbakan University & $-15.19(*)$ & 4.56 & .001 \\
\hline & & Yıldız Teknik University & $-24.22(*)$ & 5.09 & .000 \\
\hline & & Van Yüzüncü Y1l University & $-19.84(*)$ & 4.86 & .000 \\
\hline & \multirow{2}{*}{ Gaziantep University } & Y1ldı Teknik University & $-15.16(*)$ & 4.95 & .002 \\
\hline & & Van Yüzüncü Y1l University & $-10.78(*)$ & 4.71 & .022 \\
\hline & Giresun University & Yıldız Teknik University & $-10.82(*)$ & 4.66 & .021 \\
\hline & Marmara University & Yıldız Teknik University & $-11.22(*)$ & 5.37 & .037 \\
\hline
\end{tabular}

$* \mathrm{p}<0.05$

\subsection{Results Related to the Fourth Sub-problem}

In order to investigate the fourth sub-problem of the study "What are the pre-service social studies teachers' attitudes towards the profession of teaching?", arithmetic means and standard deviation values were calculated. They are presented in Table 6.

Table 6. Findings Related to the Attitudes Towards the Profession of Teaching

\begin{tabular}{|c|c|c|c|c|}
\hline Items & $\mathrm{n}$ & $\overline{\boldsymbol{X}}$ & $\mathrm{SD}$ & Response Option \\
\hline M1. Even the idea of becoming a teacher is attractive for me & 654 & 4.19 & 1.11 & Mostly Agree \\
\hline M2.I find the profession of teaching boring. & 654 & 4.19 & 1.18 & Mostly Agree \\
\hline M3.I think that teaching is a good profession for me. & 654 & 4.23 & 1.12 & Strongly Agree \\
\hline $\begin{array}{l}\text { M4. If I was required to make a selection of a profession again, I would } \\
\text { prefer teaching again. }\end{array}$ & 654 & 3.46 & 1.43 & Mostly Agree \\
\hline M5.I think that teaching is not a profession suitable for me. & 654 & 4.10 & 1.28 & Mostly Agree \\
\hline M6.I think that teaching is not suitable for my life style. & 654 & 4.19 & 1.25 & Mostly Agree \\
\hline M7.I think that teaching is not suitable for my personality. & 654 & 4.19 & 1.24 & Mostly Agree \\
\hline M8.I regret selecting teaching as a profession. & 654 & 3.97 & 1.31 & Mostly Agree \\
\hline M9.I think that I will be successful in the profession of teaching. & 654 & 4.15 & 1.06 & Mostly Agree \\
\hline
\end{tabular}


M10.I am happy having selected this branch of teaching.

M11.I believe that I will be able to cope with the difficulties I will encounter in the profession of teaching.

M12.I want to teach even in challenging conditions.

M13.I trust in myself to meet the requirements of the profession of teaching.

M14.I think that I have a special talent for teaching.

M15.I think that teaching is not a suitable profession for me.

M16.I think that the profession of teaching will provide opportunities for me to create and produce something.

M17.I think that I will be able to perform the profession of teaching in a professional manner.

M18.The idea that I will teach people the things they do not know makes me happy.

M19. I sympathize with people teaching.

M20.Tinking that I will be a teacher makes me feel frightened.

M21.I do not recommend teaching as a profession to people who need to select a profession for themselves.

M22.I think that there will be many things I will be able to do when I become a teacher.

M23.I find working conditions of teachers attractive.

M24.It is important for me to be successful in courses of pedagogical content knowledge.

M25.I like talking to people teaching.

M26.I like talking and discussing about the subjects of education, learning, teaching and the profession of teaching.

M27.I think that I will be a knowledgeable and competent teacher.

M28. I believe that teaching will make me respectable in society.

M29.I have knowingly and willingly selected the branch of teaching I am currently trained for.

M30.I have concerns about the possible problems I might encounter in the profession of teaching.

M31.I think that I will be proud of giving direction to people's lives through the teaching I will deliver.

M32.I do not like talking about the subjects of education, learning, teaching and the profession of teaching.

M33.I believe that the value I deserve will be given to me when I become a teacher.

M34.Low risk of being redundant in the profession of teaching makes me feel secure.

Total

654

654

654

654

654

654

654

654

654

$654-4.02$

654

654

654

654

654

654

654

6

654

4.17

654

654

4.11

$654-4.12$

$654 \quad 3.87$

654

3.68

654

654

4.30

654

654

654

654

3.70

3.87

4.13

3.66

4.07

3.94

4.02

4.32

4.10

4.18

3.55

4.13

3.73

4.21

3.33

3.99

3.65

3.84

3.98
1.24

1.00

Mostly Agree

1.01 Mostly Agree

1.00 Mostly Agree

1.02 Mostly Agree

1.16 Mostly Agree

1.37 Mostly Agree

1.32

Moderately Agree

.95

Strongly Agree

1.35

Mostly Agree

1.20

Mostly Agree

1.23

Mostly Agree
.77
Mostly Agree

As can be seen in Table 6, it was determined that the attitudes levels of the social studies teacher candidates towards the teaching profession are at a high level with an average of 3.98. While the item having the lowest score in the attitude scale was found to be M30 with 3.33, the item with the highest score was found to be M18 with 4.32 . 


\subsection{Results Related to the Fifth Sub-problem}

In order to investigate the fifth sub-problem of the study "Do the pre-service social studies teachers' attitudes towards the profession of teaching vary significantly depending on gender?", independent samples t-test was conducted. The results of the analysis are presented in Table 7.

Table 7. T-Test Results of Attitude Points Regarding Teaching Profession by Gender

\begin{tabular}{|c|c|c|c|c|c|c|}
\hline Gender & $\mathrm{n}$ & $\bar{X}$ & $S$ & SD & $\mathrm{t}$ & $\mathrm{p}$ \\
\hline Female & 340 & 138.91 & 25.05 & 652 & 3.53 & $.000 * *$ \\
\hline Male & 314 & 131.70 & 27.19 & & & \\
\hline
\end{tabular}

As can be seen in Table 7, the pre-service social studies teachers' attitudes towards the profession of teaching vary significantly depending on gender $(\mathrm{t}(652)=3,53, \mathrm{p}<, 01)$. The mean attitude score of the female pre-service teachers $(\bar{X}=138.91)$ was found to be significantly higher than that of the male pre-service teachers $(\bar{X}=131.70)$.

\subsection{Results Related to the Sixth Sub-problem}

In order to investigate the sixth sub-problem of the study "Do the pre-service social studies teachers' attitudes towards the profession of teaching vary significantly depending on the university attended?", one-way variance analysis (ANOVA) was conducted.

When the pre-service social studies teachers' mean attitude scores were investigated on the basis of the university attended, it was found that the highest mean attitude score was taken by the pre-service teachers attending Atatürk University $(\overline{\mathrm{X}}=141.42)$, while the lowest mean attitude score was taken by the pre-service teachers attending Dokuz Eylül University $(\overline{\mathrm{X}}=111.11)$. In order to test whether the differences between the mean scores are significant, ANOVA test was conducted and the results are presented in Table 8.

Table 8. ANOVA Results of the Attitude Regarding Teaching Profession by University

\begin{tabular}{|c|c|c|c|c|c|c|}
\hline Scale & $\begin{array}{l}\text { Source of the } \\
\text { Variance }\end{array}$ & $\begin{array}{l}\text { Sum of } \\
\text { Squares }\end{array}$ & $\mathrm{SD}$ & Mean Squares & $\mathrm{F}$ & $\mathrm{P}$ \\
\hline \multirow{3}{*}{$\begin{array}{l}\text { The Scale of Attitudes toward the } \\
\text { Profession of Teaching }\end{array}$} & Between-groups & 29795.67 & 13 & 2291.97 & 3.47 & $.000 * *$ \\
\hline & Within-groups & 422796.17 & 640 & 660.62 & & \\
\hline & Total & 452591.83 & 653 & & & \\
\hline
\end{tabular}

$* * \mathrm{p}<.01$

As can be seen in Table 8, the pre-service social studies teachers' attitudes towards the profession of teaching vary significantly depending on the university attended $(\mathrm{F}(13.640)=3.47, \mathrm{p}<.01)$.

In order to find the source of the differences observed in the pre-service teachers' attitudes towards the profession of teaching depending on the university attended as a result ANOVA, one of the Post-Hoc multi-comparison techniques, the LSD (Least Significant Difference) technique was preferred. The results of the LSD test are given in Table 9.

As can be seen in Table 9, in paired comparisons made to investigate the relationship between the pre-service teachers' attitudes towards the profession of teaching and the university they attend, a significant difference was found between Adnan Menderes University and Atatürk University in favour of Atatürk Üniversitesi and between Adnan Menderes University and Dokuz Eylül University in favour of Adnan Menderes University, between Akdeniz University and Dokuz Eylül University in favour of Akdeniz University, between Atatürk University and Dokuz Eylül University in favour of Atatürk University, between Çukurova University and Dokuz Eylül University in favour of Çukurova University, between Dicle University and Dokuz Eylül University in favour of Dicle University, between Dokuz Eylül University and Gazi University, Gaziantep University, Giresun University, Karadeniz Teknik University, Marmara University, Necmettin Erbakan University, Yıldız Teknik University and Van Yüzüncü Yıl University not in favour of Dokuz Eylül University but in favour of the other universities. 
Table 9. LSD Results of the Attitude Regarding Teaching Profession by University

\begin{tabular}{|c|c|c|c|c|c|}
\hline Scale & University (i) & University (j) & $\overline{\mathrm{X}}_{\mathrm{i}}-\overline{\mathrm{X}}_{\mathrm{j}}$ & $\mathrm{SH}$ & $\mathrm{p}$ \\
\hline \multirow{14}{*}{$\begin{array}{l}\text { The Scale of } \\
\text { Attitudes towards } \\
\text { the Profession of } \\
\text { Teaching }\end{array}$} & Adnan Menderes University & $\begin{array}{l}\text { Atatürk } \\
\text { University }\end{array}$ & $-12.55(*)$ & 5.80 & .031 \\
\hline & & Dokuz Eylül University & $17.76(*)$ & 6.31 & .005 \\
\hline & $\begin{array}{l}\text { Akdeniz } \\
\text { University }\end{array}$ & Dokuz Eylül University & $22.27(*)$ & 5.57 & .000 \\
\hline & $\begin{array}{l}\text { Atatürk } \\
\text { University }\end{array}$ & Dokuz Eylül University & $30.31(*)$ & 5.43 & .000 \\
\hline & $\begin{array}{l}\text { Çukurova } \\
\text { University }\end{array}$ & Dokuz Eylül University & $28.08(*)$ & 5.97 & .000 \\
\hline & $\begin{array}{l}\text { Dicle } \\
\text { University }\end{array}$ & Dokuz Eylül University & $24.04(*)$ & 5.17 & .000 \\
\hline & & $\begin{array}{l}\text { Gazi } \\
\text { University }\end{array}$ & $-23.92(*)$ & 6.11 & .000 \\
\hline & & $\begin{array}{l}\text { Gaziantep } \\
\text { University }\end{array}$ & $-23.58(*)$ & 5.79 & .000 \\
\hline & & $\begin{array}{l}\text { Giresun } \\
\text { University }\end{array}$ & $-26.14(*)$ & 5.44 & .000 \\
\hline & Dokuz Eylül University & $\begin{array}{l}\text { Karadeniz } \\
\text { University }\end{array}$ & $-27.70(*)$ & 5.14 & .000 \\
\hline & & $\begin{array}{l}\text { Marmara } \\
\text { University }\end{array}$ & $-21.56(*)$ & 6.31 & .001 \\
\hline & & $\begin{array}{l}\text { Necmettin } \\
\text { University }\end{array}$ & $-29.18(*)$ & 5.46 & .000 \\
\hline & & Yıldız Teknik University & $-25.21(*)$ & 6.11 & .000 \\
\hline & & Van Yüzüncü Y1l University & $-29.70(*)$ & 5.83 & .000 \\
\hline
\end{tabular}

\subsection{Conculusion}

It has been determined that the pre-service teachers' perception of self-efficacy regarding geography teaching is high. It was found that there was no statistically significant difference in terms of gender variable in the sub-dimensions of the self-efficacy scale of the social studies teacher candidates and the total of the scale. When the geography teaching self-efficacy perception levels of the social studies teacher candidates were evaluated in terms of the university variable in which they study, a significant difference was found. When it was determined between which groups the differences between universities were, it was seen that the biggest difference was in favor of Yildız Technical University between Yıldız Technical University and Dokuz Eylül University. It has been determined that social studies teacher candidates have a high level of attitude towards teaching profession. A significant difference was found in terms of gender variable according to the findings related to social studies teacher candidates' attitudes towards teaching profession. Social studies teacher candidates' attitude scores regarding the teaching profession vary significantly depending on the university where they are studying. When it was determined between which groups the differences between universities were, it was seen that the biggest difference was in favor of Atatürk University between Atatürk University and Dokuz Eylül University. 


\section{Discussion}

It has been determined that the pre-service teachers' perception of self-efficacy regarding geography teaching is high. According to the results obtained regarding the self-efficacy perception levels, it can be predicted that prospective teachers trust themselves, consider themselves sufficient in geography teaching, and that they will be an effective teacher in their future life. Karadeniz (2011) carried out his study with the scale developed by him and used as a data collection tool in this research with 164 geography and social studies teachers in Ordu. With the findings obtained from the study, it has been concluded that the self-efficacy perception levels of teachers are at the "medium" level.

It was found that there was no statistically significant difference in terms of gender variable in the sub-dimensions of the self-efficacy scale of the social studies teacher candidates and the total of the scale. Performed with various teaching programs; Regarding the geographical self-efficacy of Casız (2015), Karadeniz (2011), Simşek (2016) and Yıldırım and Şimşek (2016); In Altuntaş, Kul and Karataş (2016), Nakip (2015), Şahin (2013) 's studies on teaching self-efficacy, the finding that there is no significant difference on self-efficacy by gender variable is supported. Ozturk (2011) which was developed by "Social Studies Learning Social Studies Teachers and Teachers Relating to Space Self Efficacy Scale" with Turkey in social information within the province are determined on the NUTS 1 level with last year student teaching universities in the study carried out in the provinces where available; As a result of the findings obtained from 3106 teachers and 449 teacher candidates, he stated that there was no significant difference between self-efficacy and gender. As a matter of fact, gender variable does not have a significant effect on self-efficacy perception. As the reason for the self-efficacy perceptions to be similar, the fact that women and men are educated in line with the same academic goals by co-education in academic life and thus developing a similar concept of academic self might have affected their not being differentiated in terms of their self-efficacy perceptions "(Akbaş and Çelikkaleli, 2006, p. 106).

When the geography teaching self-efficacy perception levels of the social studies teacher candidates were evaluated in terms of the university variable in which they study, a significant difference was found. When the self-efficacy perception levels are evaluated in terms of the university variable in which they are studying, similar results are found in studies of Casız (2015), Öztürk (2011) and Şimşek (2016). When it was determined between which groups the differences between universities were, it was observed that the biggest difference was in favor of Yildiz Technical University between Yıldız Technical University and Dokuz Eylül University. When the average of total geography self-efficacy is analyzed according to the university variable where the pre-service teachers study; while the highest average belongs to Yıldız Technical University, the lowest average belongs to Dokuz Eylül University. This result shows that pre-service teachers studying at Yıldı Technical University consider themselves more sufficient in terms of geography teaching than the pre-service teachers in all other universities in the sample. The result that Dokuz Eylul University has a long history of education is a surprising finding. Akbaş and Çelikkaleli (2006) found a significant difference according to the university variable as a result of their studies on pre-service teachers and their self-efficacy beliefs about science education. When the source of the difference was determined, it was concluded that teacher candidates at Dokuz Eylül University had higher self-efficacy perceptions than teacher candidates at Mersin University.

It has been determined that social studies teacher candidates have a high level of attitude towards teaching profession. In line with the high attitude levels, it can be thought that prospective teachers have a positive attitude towards the profession, they are interested in the profession of teaching, they choose the profession voluntarily and they can be a model teacher who loves their profession in their future lives. It can be said that those who have a positive attitude towards their profession will be teachers who achieve success by pushing their limits and are open to development. There are similar studies equivalent to the findings of the research (Altun, 2015; Bulut, 2009; Karatekin, Merey \& Keçe, 2015).

A significant difference was found in terms of gender variable according to the findings related to social studies teacher candidates' attitudes towards teaching profession. It has been observed that there is a significant relationship between female teacher candidates 'attitude scores regarding teaching profession and male teacher candidates' attitude scores in favor of female candidates. According to the data obtained by Akdağ (2014), Aydın and Sağlam (2012), İlter (2009), Seferoğlu (2004), Yakar and Yelpaze (2019), there is a result in favor of female participants. In this context, we can say that female candidates have a more positive attitude towards teaching profession and are more prone to male candidates. Turkey women's personality traits across the teaching profession a profession that is dominated by the more appropriate blood. Teaching profession is a profession that we associate with beautiful feelings such as love, compassion and compassion. It is a known fact that the representatives of these emotions are women. It is the studies on the differences in the attitudes of men and women towards the teaching profession, 
proving this view numerically. Kubiatko and Arık (2014) were conducted with 27 theses by meta-analysis method to measure the effect of gender on the attitude towards teaching profession. $T$ of the studies examined as a result of the analysis explains that women exhibit a more positive attitude towards the teaching profession than men. Another similar meta-analysis study was done by Atalmış and Köse (2018). As a result of the analysis conducted with 106 studies containing gender variable, it was revealed that female teacher candidates have a more positive attitude. Şahin (2013) did not find a significant difference between the attitude towards the teaching profession and the gender variable in his study with prospective teachers participating in pedagogical formation education. Alnaas (2017), Bulut (2009), Çakır, Kan and Sünbül (2006), Demirtaş et al. (2011) reached similar results in Karakuş (2017).

Social studies teacher candidates' attitude scores regarding the teaching profession vary significantly depending on the university where they are studying. When it was determined between which groups the differences between universities were, it was seen that the biggest difference was in favor of Atatürk University between Atatürk University and Dokuz Eylül University. Attitude scores differ significantly depending on the university where the education is studied and when the average of attitudes towards teacher profession according to the university variable where the pre-service teachers study at; while the highest average belongs to Atatürk University, the lowest average belongs to Dokuz Eylül University. This result shows that the pre-service teachers studying at Atatürk University show a more positive attitude towards the teaching profession compared to the pre-service teachers studying at Dokuz Eylül University. Therefore, we can think that pre-service teachers go through different learning experiences and education programs. Bulut (2009) did not reach a conclusion towards a significant differentiation in terms of the university variable in his attitude towards the profession with 411 prospective teachers from Dicle University and Firat University. As can be seen, the result of the study does not coincide with this research.

\subsection{Suggestions}

Apart from the variable addressed in the current study, the effects of different variables such as academic achievement, the reason for the selection of the profession of teaching, type of the high school graduated, economic status of the family, the presence of a teacher in the family and desire to be a teacher after completing the undergraduate education on self-efficacy perception and attitudes towards the profession can be investigated.

Similar studies are generally conducted in one university and even when they are conducted in different universities, the university attended is not included within the variables addressed. In future research, different universities can be included and attempts can be made to determine the reasons for difference by asking questions to elicit data about the physical, academic etc. conditions of universities.

The data collection tools used in the current study on pre-service social studies teachers can be administered to pre-service teachers and teachers from different branches.

In order to increase the number of self-efficacy studies on geography teaching, the scale used in the current study can be administered to students enrolled in the departments of geography teaching and elementary school teaching which include geography in their content area.

In order to provide a correct guidance for secondary school students wanting to be a teacher, research can be conducted to determine these students' self-efficacy and attitudes regarding the profession of teaching.

\subsection{The Limitations}

1. The research is limited to 14 universities determined as samples.

2. Applications are limited to the Spring semester of 2017-2018 academic year.

3. The data collection tools of the research are limited to "Self-Efficacy Scale Related to Teaching Geography" and "Attitude Scale Related to Teaching Profession".

4. The self-efficacy scale is limited to teaching geography from the disciplines of the social studies course.

5. The sample is limited only to fourth grade students teaching social studies.

6. Research self-efficacy and attitude as a dependent variable are limited to the university where gender and education are the independent variables.

Above are the limitations of the study. 


\section{References}

Akbaş, A., \& Çelikkaleli, Ö. (2006). Sınıf öğretmeni adaylarının fen öğretimi özyeterlik inançlarının cinsiyet, öğrenim türü ve üniversitelerine göre incelenmesi. Mersin Üniversitesi Eğitim Fakültesi Dergisi, 2(1), 98-110.

Akdağ, S. (2014). Sosyal bilgiler ögrretmeni adaylarının öğretmenlik mesleğine yönelik tutumlarının bazı değişkenler açısından incelenmesi (Erzurum örneği) (Yayımlanmamış Yüksek Lisans Tezi). Atatürk Üniversitesi Eğitim Bilimleri Enstitüsü, Erzurum.

Akengin, H., Şahin, C. T., Kaya, B., Bengiç, G., \& Sargın, S. (2010). Sosyal bilgiler öğretmen adaylarının bazı genel coğrafya konuları ve bunların öğretimi ile ilgili öz-yeterlik algıları. Marmara Coğrafya Dergisi, 21, 78-97.

Aliyev, R. (2015). Sosyal bilişsel öğrenme. In Ş. Işık (Ed.), Eğitim Psikolojisi, 412-437. Ankara: Pegem.

Allport, G. W. (1935). Attitudes. In C. A. Murchison (Ed.), A handbook of Social Psychology, 798-884. Worcester, Massachusetts: Clark University Press.

Alnaas, R. S. M. (2017). Öğretmen adaylarının öğretmenlik mesleğine yönelik tutumları ve ögretmen öz-yeterlilik düzeyleri arasındaki ilişskinin incelenmesi (Yayımlanmamış Yüksek Lisans Tezi). Kastamonu Üniversitesi Fen Bilimleri Enstitüsü, Kastamonu.

Altun, T. (2015). Pedagojik formasyon eğitimi alan öğretmen adaylarının öz-yeterlik inançlarl, öğretmenlik mesleğine iliş̧kin tutumlart ve kaygı düzeyleri arasındaki iliş̧kinin incelenmesi (Yayımlanmamış Yüksek Lisans Tezi). Akdeniz Üniversitesi Eğitim Bilimleri Enstitüsü, Antalya.

Altuntaş, E. A., Kul, M., \& Karataş, İ. (2016). Beden eğitimi öğretmeni adaylarının öğretmenlik mesleğine ilişkin tutumları ile öz yeterlikleri arasındaki ilişki. International Journal of Contemporary Educational Studies, 2(2), 196-215.

Atalmış, E. H., \& Köse, A. (2018). Türkiye'deki öğretmen adaylarının öğretmenlik mesleğine yönelik tutumları: Bir meta-analiz çalışması. Eğitimde ve Psikolojide Ölçme ve Değerlendirme Dergisi, 9(4), 393-413. https://doi.org/10.21031/epod.410287

Aydın, R., \& Sağlam, G. (2012). Öğretmen adaylarının öğretmenlik mesleğine yönelik tutumlarının belirlenmesi (Mehmet Akif Ersoy Üniversitesi örneği). Türk Eğitim Bilimleri Dergisi, 10(2), 257-294.

Bandura, A. (1994). Self-efficacy. In V. S. Ramachaudran (Eds.), Encyclopedia of human behavior, 71-81. New York: Academic Press.

Bandura, A. (1997). Self-efficacy: The exercise of control. New York: W H Freeman and Company.

Bilgili, A. S. (2009). Sosyal bilgilerin temelleri. Ankara: Pegem.

Bulut, İ. (2009). Öğretmen adaylarının öğretmenlik mesleğine ilişkin tutumlarının değerlendirilmesi (Dicle ve Fırat Üniversitesi örneği). Dicle Üniversitesi Ziya Gökalp Eğitim Fakültesi Dergisi, 14, 13-24.

Büyüköztürk, Ş., Kılıç, Ç. E., Akgün, Ö. E., Karadeniz, Ş., \& Demirel, F. (2010). Bilimsel Araştırma Yöntemleri. Ankara: Pegem.

Büyüköztürk, Ş. (2019). Sosyal bilimler için veri analizi el kitabı. Ankara: Pegem. https://doi.org/10.14527/9789756802748

Brownell, M. T., \& Pajares, F. (1999). Teacher Efficacy and perceived success in mainstreaming students with learning and behavior problems. Teacher Education and Special Education. 22(3), 154-164. https://doi.org/10.1177/088840649902200303

Cansız, M. (2015). Coğrafya öğretmen adaylarının ortä̈ğretim coğrafya müfredatında yer alan coğrafya konularını ögretmedeki mesleki öz yeterlilik algıları (Yayımlanmamış Yüksek Lisans Tezi). Marmara Üniversitesi Eğitim Bilimleri Enstitüsü, İstanbul.

Cebeci, S. (2014). Bilimsel araştırma ve yazma teknikleri. İstanbul: Alfa.

Çakır, Ö., Kan, A., \& Sünbül, Ö. (2006). Öğretmenlik meslek bilgisi ve tezsiz yüksek lisan programlarının tutum ve özyeterlik açısından değerlendirilmesi. Mersin Üniversitesi Eğitim Fakültesi Dergisi, 2(1), 36-47.

Çapri, B., \& Çelikkaleli, Ö. (2008). Öğretmen adaylarının öğretmenliğe ilişkin tutum ve mesleki yeterlik inançlarının cinsiyet, program ve fakültelerine göre incelenmesi. İn̈̈n̈̈ Üniversitesi Eğitim Fakültesi Dergisi, 9(15), 33-53.

Demirel, Ö., \& Kaya, Z. (Ed.). (2005). Öğretmenlik mesleğine girişs. Ankara: Pegem. https://doi.org/10.14527/9786052413128 
Demirtaş, H., Cömert, M., \& Özer, N. (2011). Öğretmen adaylarının özyeterlik inançları ve öğretmenlik mesleğine ilişkin tutumları. Ëgitim ve Bilim, 36(159), 96-111.

Erden, M. (2007). Eğitim bilimine giriş. Ankara: Arkadaş.

Gömleksiz, M. N., \& Kan, A. (2013). Sosyal bilgiler dersi tutum ölçeğinin geçerlik ve güvenirlik çalışması. Fırat Üniversitesi Sosyal Bilimler Dergisi, 23(2), 139-148.

İlter, İ. (2009). Öğretmen adaylarının öğretmenlik mesleğine ilişkin tutumlarının bazı değişsenler açısından incelenmesi (Yayımlanmamış Yüksek Lisans Tezi). Fırat Üniversitesi Sosyal Bilimler Enstitüsü, Elazı̆̆g.

Kaçar, R. (2018). Sosyal bilgiler öğretmen adaylarının ögrretmenlik mesleğine yönelik tutum ve özyeterlik alglları (Unpublished Master Thesis). Fırat Üniversitesi Eğitim Bilimleri Enstitüsü, Elazığ.

Karadeniz, C. B. (2011). Öğretmenlerin coğrafya öz-yeterlik inançları (Ordu ili örneği). Eğitim Bilim Toplum Dergisi, 9(35), 28-47.

Karadeniz, B. C., \& Sarı, S. (2011). Coğrafya öğretimi öz-yeterlik ölçeğinin geliştirilmesi. Eğitim Bilim Toplum Dergisi, 9(33), 9-27.

Karakuş, İ. (2017). Öğretmen adaylarının öz yeterlik inançları ile öğretmenlik mesleğine yönelik tutumları arasindaki ilişkinin incelenmesi (Yayımlanmamış Yüksek Lisans Tezi). Kahramanmaraş Sütçü İmam Üniversitesi Sosyal Bilimler Enstitüsü, Kahramanmaraş. https://doi.org/10.18020/kesit.1178

Karasar, N. (2013). Bilimsel araştırma yöntemi. Ankara: Nobel.

Karatekin, K., Merey, Z., \& Keçe, M. (2015). Sosyal bilgiler öğretmen adaylarının öğretmenlik mesleğine yönelik tutumları. Yüzüncü Yll Üniversitesi Eğitim Fakültesi Dergisi, 12(1), 70-96.

Kubiatko, M., \& Arık, R. S. (2014). Comparison of the effects of gender variable on attitudes towards the teaching profession by random and fixed effects model: Meta-analysis. Educational Process: International Journal, 3(1-2), 52-64. https://doi.org/10.12973/edupij.2014.312.4

Nakip, C. (2015). Öğretmen adaylarının öğretmenlik mesleğine yönelik öz-yeterlik inançları ile öğretmenlik mesleğine yönelik tutumları arasındaki ilişki (Yayımlanmamış Yüksek Lisans Tezi). Abant İzzet Baysal Üniversitesi Eğitim Bilimleri Enstitüsü, Bolu.

Schriver, M. L., \& Czerniak, C. M. (1999). An examination of preservice science teachers' beliefs and behaviors as related to self-efficacy. Journal of Science Teacher Education, 5, 77-86. https://doi.org/10.1007/BF02614577

Seferoğlu, S. S. (2004). Öğretmen adaylarının öğretmenliğe yönelik tutumları. XII. Eğitim Bilimleri Kongresi: Bildiriler I içinde, 413-423, Gazi Üniversitesi Eğitim Bilimleri Enstitüsü, Ankara.

Şahin, H. (2013). Self-efficacy and attitudes of the teacher candidates who participated in pedagogical formation training. Academic Journals, 8(21), 2083-2092.

Şimşek, M. (2016). Sosyal bilgiler öğretmen adaylarının coğrafyaya yönelik öz-yeterlik düzeylerinin ve tutumlarının incelenmesi (Yayımlanmamış Doktora Tezi). Marmara Üniversitesi Eğitim Bilimleri Enstitüsü, İstanbul.

Tabachnick, B., \& Fidell, L. S. (2015). Çok değişkenli istatistiklerin kullanımı. Ankara: Nobel.

TBMM Legislation Information System (2019). National Education basic law. Retrieved from https://mevzuat.tbmm.gov.tr/mevzuat/faces/kanunmaddeleri?pkanunlarno $=41798 \&$ pkanunnumarasi $=1739$

Üstüner, M. (2006). Öğretmenlik mesleğine yönelik tutum ölçeğin geçerlik ve güvenirlik çalışması. Kuram ve Uygulamada Ĕ̈itim Yönetimi, 12(45), 109-127.

Yakar, L., \& Yelpaze, İ. (2019). Öğretmen yetiştiren programlara kayıtlı öğrencilerin öğretmenlik mesleğine yönelik tutumları ve ögretmen öz-yeterlik algıları. Pamukkale Üniversitesi Eğitim Fakültesi Dergisi, 47, 107-129. https://doi.org/10.21764/maeuefd.651393

Yaman, S., Koray, Ö. C., \& Altunçekiç, A. (2004). Fen bilgisi öğretmen adaylarının öz-yeterlik inanç düzeylerinin incelenmesi üzerine bir araştırma. Türk Ĕgitim Bilimleri Dergisi, 2(3), 355-364.

Yıldırım, T., \& Şimşek, Ü. (2016). Sosyal bilgiler öğretmenliği öğrencilerinin coğrafya alanına yönelik öz-yeterliklerinin farklı değişkenler açısından incelenmesi. Marmara Coğrafya Dergisi, 34, 43-49. 